Eleni T. Stavrou, Chris Brewster*

\title{
The Configurational Approach to Linking Strategic Human Resource Management Bundles with Business Performance: Myth or Reality? ${ }^{* *}$
}

Strategic human resource management has been linked to competitive advantage and in turn to organizational performance. This linkage has been viewed from a universal, a contextual or a configurational perspective. Adopting the latter perspective, the authors of the present study investigate the possible Strategic HRM Bundles of competitive advantage within the EU and the extent to which these bundles are linked to business performance. The exploration revealed fifteen bundles: six of which have a positive and one has a negative relation to performance. These results raise theoretical as well as practical implications about the extent to which HRM is viewed strategically within the EU business context.

Key words: Business Performance, Competitive Advantage, Strategic Human Resource Management

Eleni T. Stavrou, University of Cyprus, Department of Pubic and Business Administration,75 Kallipoleos Avenue, Nicosia, CYPRUS 1678, Tel. +357-22892480, Fax. +35722892460, e-mail: eleni1@ucy.ac.cy-

Chris Brewster, Henley Management College, Henley Management College, Greenlands, Henley-on-Thames, Oxfordshire, RG9 3AU, UK, phone: +44 1491 414529, fax: +44 1491 571635, e-mail: chris.Brewster@henleymc.ac.uk.

** Acknowledgement: We would like to express our appreciation to the colleagues of the EU member countries part of CRANET that gave me permission to use their data.

Article received: February 27, 2004

Revised version accepted after double blind review: February 16, 2005. 


\section{Introduction}

Researchers have linked strategic human resource management to competitive advantage and, in turn, to business performance (Ulrich/Lake 1990; Pickles et al. 1999). To illustrate, Ferris et al. (1999) argued that few of the more traditional sources of competitive advantage create sustainable worth for the organization, while strategic human resource management can create the required value for the organization to help establish a sustainable competitive advantage. Strategic Human Resource Management (SHRM) provides requisite links between HRM and the strategic management processes of the organization (Taylor/Beechler/Napier 1996). Fundamental to the SHRM perspective is the assumption that firm performance is directly related to the set of HRM practices firms have in place (Huselid/Jackson/Schuler 1997).

However, in practice SHRM seems far from being applied as a competitive tool linked to business performance (Harris/Ogbonna 2001). As examples, Brewster (1995) reports that the integration of human resource management to business strategy is rare even among large organizations; Down et al. (1997) report that many management teams have had difficulty transforming human resource management into a strategic function, leaving the human resources department in most companies focused on administrative and clerical tasks.

In their attempt to explore the HRM-performance relationship empirically, researchers have identified different human resource management practices as crucial to sustainable competitive advantage (Flanagan/Deshpande 1996; Pfeffer/Veiga 1999; Ferris et al. 1999). However, no consensus exists in relation to the specific practices to be employed (Ferris et al. 1999; Boxal/Steeneveld 1999). Further, the systematic categorization of these practices into "Strategic HR Bundles" and their connection to performance is missing from existing research (MacDuffie 1995). Even so, a number of studies utilizing "bundles" of different management practices have shown the effects of these bundles on organizational performance to be much greater than when such practices are explored individually (MacDuffie 1995; Ichniowski/Shaw/ Prennushi 1997; Perry-Smith/Blum 2000).

Finally, while the connection between HRM and performance has been extensively researched in the US, very few studies on the subject have been conducted in Europe. Yet the European Union (EU) is increasingly successful economically and stands out as distinct from other economic areas like the USA or Asia (Brewster 1995). Brewster, Mayrhofer, and Morley (2004) emphasize the necessity to explore HRM approaches that are indigenous to the EU.

The present study is pursued in the EU context and has two aims. The first is to use the configurational approach to find the possible Strategic HRM Bundles of competitive advantage and the second is to investigate the extent to which these bundles are linked empirically to business performance. As measures of performance we combine profitability, productivity and service quality (Huselid 1995; Delaney/ Huselid 1996; Fox et al. 1999). 


\section{Strategic Human Resource Management and Performance}

The strategic importance of human resources has been widely recognized (Swiercz/ Spencer 1992; Huselid 1995; Pfeffer/Veiga 1999). As a result, strategic human resource management (SHRM) has been argued to be positively related to organizational performance (Huselid 1995; Huselid/Jackson/Schuler 1997; Harris/Ogbonna 2001). More specifically, HRM has been linked to increased productivity (MacDuffie 1995; Ichniowski/Shaw/Prennushi 1997; Fox et al. 1999), good customer service (Fox et al. 1999), improved efficiency (Becker/Gerhart 1996), increased firm value (Huselid 1995), greater profitability or financial returns (Delery/Doty 1996; Becker et al. 1996; Fox et al. 1999) and overall organizational survival (Welbourne/ Andrews 1995).

Snell, Youndt, and Wright $(1996,62)$ characterized the strategic role of HRM as "organizational systems designed to achieve competitive advantage through people." In turn, competitive advantage may be defined as a set of capabilities or resources giving an organization an advantage that leads to superior performance relative to that of competitors (Wiggins/Ruefli 2002, p. 84). In this respect, the main focus of SHRM is on integrated combinations of HRM practices, through which organizations should create competitive advantage rather than simply adapting to the existing context (Snell/Youndt/Wright 1996; Pickles/Bookbinder/Watts 1999). A review of the literature reveals five interrelated approaches to the link between the competitive position of an organization and the creation of superior human assets.

\subsection{Human Resources and Competitive Advantage}

First, the resource-based approach of competitive advantage focuses on the relationships between a firm's internal resources, its profitability and the ability to stay competitive through its strategy formulation (Delery 1998; Ferris et al. 1999; Koch/McGrath 1996; Gannon et al. 1999). According to this approach, a resource is considered as an internal strength only if it meets the five criteria for sustainable competitive advantage (Barney 1991; Gannon et al. 1999). Specifically, a resource must (1) be immobile; (2) be difficult to replicate; (3) have no close substitutes; (4) be rare; and (5) create value (Elsdon/Iyer 1999; Ferris et al. 1999; Dube/Renaghan 1999; Jackson/Schuler 2000; Gannon et al. 1999). The central idea of the resource-based theory is that a firm's systems, among its other attributes, enable the organization to achieve success relative to competitors (Taylor/Beechler/Napier 1996).

A second approach poses some questions as to the effectiveness of the resourcebased approach within a dynamic and constantly changing environment (Snell et al. 1996; Barney 2001). This approach is based on the fact that innovation, change and organizational renewal are becoming more critical sources of competitive advantage, and therefore more important in sustaining a given position, than resources proposed by the resource-based approach. According to this second approach, the firm's ability to learn faster than its competitors could be the only sustainable competitive advantage, because organizational learning expands the firm's knowledge base, the range of potential behaviors and its capacity for adaptation. The processes of organizational learning that lead to sustainable competitive advantage are the creation, transfer and 
institutionalization of knowledge that combines the five criteria of sustainable competitive advantage (Snell et al. 1996).

A third approach focuses on the way human resource systems support competitive advantage and organizational learning through people. This perspective implies that human resource management should focus on how the integration of organizational resources, practices and capabilities can lead to sustainable competitive advantage. To understand this integration researchers have used notions of internal or horizontal fit and external or vertical fit (Delery 1998; Ferris et al. 1999). Management must have a clear understanding of internal fit and the way such fit facilitates organizational learning and adaptation. For example, multifunctional systems of human resource practices will lead to sustainable competitive advantage if they add value, are causally ambiguous and are socially complex. Furthermore, practices with external fit create capabilities that maintain the organization's overall strategy and support multiple strategic dimensions in order to lead to sustainable competitive advantage.

Bernardin and Russell (1993) have developed a fourth approach, outlining three alternative ways that human resource management can lead to sustainable competitive advantage. First, human resource management can take an active role in the organization's change process, as the organization adapts to the continuously changing environment. Second, human resource management can help the organization that wants to survive and remain competitive to look continually for environmental threats and opportunities and internal strengths and weaknesses, so that the appropriate strategies are designed. Third, human resource management can lead to sustainable competitive advantage by acting as the linking-pin between stakeholders and the business by creating strategic unity through the appropriate practices.

Finally, Lado et al. (1992) proposed a competency-based model for sustainable competitive advantage through human resource management. Expanding the resource-based approach, the competency-based model addresses managerial, input-based, transformational and output based organizational competencies. These organizational competencies can enhance sustainable competitive advantage to the extent that human resource management facilitates the development and effective exploitation of them.

On the basis of the above five approaches, researchers proposed a number of human resource practices that, if employed strategically, would lead to sustainable competitive advantage (Delaney et al. 1989; Pfeffer 1994; Huselid 1995; Koch/ McGrath 1996; Flanagan/Deshpande 1996; Delery/Doty 1996). However, none of the above approaches has proved better than any other in identifying the specific HR practices that are most closely related to organizational competitiveness. As Ferris et al. (1999) note, all approaches are subject to many of the same limitations and offer little consensus: in particular with regard to precisely which HRM practices should be included. In addition, questions are raised in the literature as to whether these practices are universal or context specific, and if the latter, then which practices are appropriate for achieving fit to the various contexts investigated (Ferris et al. 1999; Boxal/Steeneveld 1999).

To illustrate, universalists such as Pfeffer (1994) and Osterman (1994) argue that greater use of "high performance" practices such as participation and empowerment, 
incentive pay, employment security, promotion from within, and training and skill development result in higher productivity and profits across organizations. By contrast, contingency theorists note how a number of HRM practices are consistent with different strategic positions and how these practices relate to firm performance. And a third group, configurational theorists have attempted to integrate patterns of SHRM-related practices and test their effects on performance: for example, Delery and Doty (1996) compare practices within two configurational systems, namely the internal and the market systems. Finally here, Huselid, Jackson, and Schuler (1997), cite activities such as compensation systems, team-based job designs, flexible workforces, quality improvement practices, employee empowerment, and planned development of the talent required to implement competitive strategy and achieve operational goals. However, they note that for these SHRM activities, little shared understanding and few regulatory guidelines exist as to how to achieve effective implementation; in addition, occupational specialization is not yet apparent. Given these conditions, effective SHRM activities will be relatively rare across a population of firms (Huselid/ Jackson/ Schuler 1997).

\subsection{Human Resources and the Configurational Approach}

Adopting the configurational approach to SHRM, Ichniowski et al. (1997) explain that when HRM practices are combined in different forms, the effects on organizational performance are much greater than when practices are explored individually. Furthermore, Marchington and Grugulis (2000: 1112) explain that HRM practices "cannot be implemented effectively in isolation and that it is the combination of practices into a coherent package that matters." Taking this argument a step further, MacDuffie (1995) argues that the appropriate unit of analysis for studying the strategic link between different HRM practices to performance does not involve individual practices as much as interrelated and internally consistent practices, called "bundles." He explains that a "bundle" creates the multiple, reinforcing conditions that support employee motivation, given that employees have the necessary knowledge and skills to perform their jobs effectively.

Along the same lines of argumentation, Perry-Smith and Blum (2000) suggest that HR bundles capture broader and higher-level effects than those captured by focusing on individual policies and are particularly appropriate for investigating firm-level effects. According to the same authors, the bundle approach is consistent with ideas advanced in SHRM research and can create the conditions for effective economic performance, where human resources can be a primary source of sustainable competitive advantage. Employee behaviors that are embedded in routine, complex interaction patterns and organizational-specific synergies can create organizational capabilities that create value, are difficult to imitate, rare and immobile (MacDuffie 1995; PerrySmith/Blum 2000).

\subsection{Human Resources in the EU}

The majority of the above frameworks and studies have been developed and conducted in the US. Given that these frameworks and studies may serve as a platform for further study, the need to understand HRM from a European perspective, 
separately from the US, has become a common theme in international literature. Even though not homogenous, the EU serves as a collective context, abiding to certain collective regulations, practices and norms (Sparrow/ Hiltrop, 1997; Brewster/ Mayrhofer/ Morley, 2004). In fact, the European Commission has set as a goal making the EU the most competitive knowledge-based economy in the world, capable of sustainable economic growth. In this context, the establishment of an indigenous set of SHRM bundles of competitive advantage could gradually help establish policies common for and applicable to all EU Member States.

\section{Methodology}

Given the aforementioned discussion, this study focuses on bundles rather than individual SHRM practices and their connection to performance within the EU. The specific research questions of the present study are the following:

a) Which are the Strategic HR Bundles of competitive advantage in the EU?

b) Is each of these Bundles positively related to Business Performance?

\subsection{Data}

Data were collected through the CRANET questionnaire, the product of an international team of academics conducting research on human resource management over the past 13 years (see Brewster/Mayrhofer/Morley 2004 for details on the questionnaire and its methodology). The questionnaire is structured with eighty composite closed-ended questions, each of which presents a number of options/items, covering all facets of HR management. Twenty-one of those questions were used for the present study.

The unit of analysis of the questionnaire is the organization and the respondent is the highest-ranking corporate officer in charge of human resource management. For this study fourteen out of the fifteen EU member states prior to May 2004 have been included in the analysis (the exception was Luxembourg due to lack of a sufficient sample of organizations). The samples in each country have been selected from lists provided by the national federations, such as chambers of commerce or national statistical services. The final sample of organizations for the EU member states utilized in the analysis was 3702 for-profit businesses. Researchers ensure that all sectors of the economy are represented so that samples in the CRANET database are demonstrative of the population of organizations in each country. Finally, to improve the content validity, response reliability, and response rates, the survey was conducted in the manner suggested by Podsakoff, et al.(2003).

\subsection{Measures and Analysis}

The dependent variable, called Business Performance, is a composite measure of Profitability, Productivity and Service Quality. Each of these three measures on the questionnaire involves the perceptions of study participants as to the performance of their organization in comparison with that of competitors. Specifically, participants are requested to state whether their business is at the top $10 \%$ (1) or not (0) compared to competitors in terms of profitability, service quality and productivity separately. Comparing actual performance measures is difficult; and particularly difficult across na- 
tional boundaries (Lahteenmaki/Vanhala 1998). The use of a perceptual performance measure, even though not optimal, is acceptable and consistent with prior research (e.g. Smith/Barcley 1997; Perry-Smith/Blum 2000; Jap 2001). Pearce, Robbins, and Robinson (1987) found that senior managers' perceptions of performance were consistent with financial and other measures

In this study, the three measures have been combined into a composite one (see Delaney/Huselid 1996; Sherman/Young/Collingwood 2003 on using such composite measures) by taking those businesses that are either top $10 \%(1,1,1)$ or not $(0,0,0)$ in all three measures, while excluding all other in-between cases from the analysis. Borrowing from other disciplines, this measure of performance was chosen since often a $0-100 \%$ evaluation scale is used, and the minimum for excellence is to be among the top 10\% (Hax/Wilde 1999; Rank/Hirschl 2001; Kerr/Beaujot 2002; Blum/Clegg 2003). In addition, to explore empirically the appropriateness of combining these three measures, Principal Components Analysis with varimax rotations was conducted (Tabachnick/Fidell 2000). This analysis revealed a single factor with loadings 728 for service quality, .834 for productivity and .791 for profitability, offering empirical support for the combined measure. All performance measures were posed at the end of the questionnaire and after a set of organizational demographic information.

The independent variables are called Strategic HR Bundles and are created as follows: (a) a comprehensive review of the literature on the subject has revealed a number of HR practices related strategically to competitive advantage and organizational performance; (b) these practices were operationalized through the variables on the CRANET questionnaire; given the lack of consensus in the literature on the specific practices to be used, the authors sought not to exclude any practices cited; (c) in turn, 80 variables were operationalized (see Appendix 1); the practices used in the businesses studied were attributed a value of one (1), otherwise they received a value of zero (0); (d) in order to create the Strategic HR Bundles from these variables, the authors used Principle Components Analysis (MacDuffie 1995; Delery 1998).

To create the factor score coefficients, the authors used Varimax rotation and the Anderson-Rubin method which ensure orthogonality of the estimated factors; therefore the resulting scores are uncorrelated with a mean of 0 and a standard deviation of 1. Consistent with the work of Huselid, Jackson and Schuler (1997) and due to the large sample size (Tabachnick? Fidell, 2000), the minimum correlation coefficient set for an item to be classified into a factor was .40. Subsequently, the resulting factors (Strategic HR Bundles) were used as continuous independent variables, since they were derived directly from the factor analysis (Tabachnick/ Fidell, 2000). Finally, to test the relationship between each Strategic HR Bundle and Business Performance, the authors used logistic regression since the performance measure was categorical and binary (Tabachnick/Fidell, 2000; Shrader, 2001). All analyses used an alpha level of 0.05.

\section{Results}

First, the authors conducted Principal Components Analysis to find the Strategic HR Bundles. The analysis was conducted four times, since each time items that were not grouped in any factor (below .40) had to be deleted from the list. The variables excluded from the final analysis are the following (see Appendix 1): organizations with a 
human resource management department; the head of HR participating on the governing board; organizations with HR strategy; HR involvement in corporate strategy; regular use of assessment centers; evaluation system used in career development; workplace childcare; childcare allowances; career break schemes; maternity leave beyond that required by law; paternity leave beyond that required by law; pension schemes; education/training breaks; vacancies filled internally for senior, middle and junior management; communication verbally direct to employees; communication written to employees; communication through computer mail. In the fourth round, the analysis revealed 15 Strategic HR Bundles. The rotation converged in 6 iterations.

Table 1: Principal Components Analysis of HRM Practices into Strategic HR Bundles in the European Union

\begin{tabular}{|c|c|c|}
\hline $\begin{array}{l}\text { Strategic Human Resource } \\
\text { Bundles (Factors) }\end{array}$ & $\begin{array}{l}\text { Human Resource Practices included in each } \\
\text { Bundle (Factor) }\end{array}$ & $\begin{array}{l}\text { Factor } \\
\text { Loadings }\end{array}$ \\
\hline $\begin{array}{l}\text { 1. Training Bundle } \\
\text { Eigenvalue: } 3,48 \\
\% \text { of Variance Explained: } 5,70\end{array}$ & $\begin{array}{l}\text { Analyze employee training needs } \\
\text { Monitor effectiveness of training } \\
\text { Evaluate training through learning } \\
\text { Evaluate training through behaviors } \\
\text { Evaluate training through results } \\
\text { Evaluate training through reactions }\end{array}$ & $\begin{array}{l}, 45 \\
, 89 \\
, 53 \\
, 82 \\
, 76 \\
, 85\end{array}$ \\
\hline $\begin{array}{l}\text { 2. Share-Options Bundle } \\
\text { Eigenvalue: } 3,43 \\
\% \text { of Variance Explained: } 5,62\end{array}$ & $\begin{array}{l}\text { Offer employee share options for management } \\
\text { Offer employee share options for professional } \\
\text { staff } \\
\text { Offer employee share options for clerical staff } \\
\text { Offer employee share options for manual staff }\end{array}$ & $\begin{array}{l}, 83 \\
, 95 \\
, 96 \\
, 91\end{array}$ \\
\hline $\begin{array}{l}\text { 3. Evaluation of HR Bundle } \\
\text { Eigenvalue: } 3,29 \\
\% \text { of Variance Explained: } 5,39\end{array}$ & $\begin{array}{l}\text { Performance of HR dept. evaluated on a sys- } \\
\text { tematic basis } \\
\text { Views of top management taken into account } \\
\text { for evaluation } \\
\text { Views of line management taken into account } \\
\text { for evaluation } \\
\text { Employee views taken into account for evalua- } \\
\text { tion } \\
\text { Human resource managers' views taken into } \\
\text { account for evaluation }\end{array}$ & $\begin{array}{l}, 84 \\
, 81 \\
, 80 \\
, 72 \\
, 71\end{array}$ \\
\hline $\begin{array}{l}\text { 4. Profit-Sharing Bundle } \\
\text { Eigenvalue: } 3,20 \\
\% \text { of Variance Explained: } 5,25\end{array}$ & $\begin{array}{l}\text { Offer profit sharing options for management } \\
\text { Offer profit sharing options for professional } \\
\text { staff } \\
\text { Offer profit sharing options for clerical staff } \\
\text { Offer profit sharing options for manual staff }\end{array}$ & $\begin{array}{l}, 82 \\
, 93 \\
, 94 \\
, 88\end{array}$ \\
\hline $\begin{array}{l}\text { 5. Group-Bonus Bundle } \\
\text { Eigenvalue: } 2,81 \\
\% \text { of Variance Explained: } 4,61\end{array}$ & $\begin{array}{l}\text { Offer group bonus for management } \\
\text { Offer group bonus for professional staff } \\
\text { Offer group bonus for clerical staff } \\
\text { Offer group bonus for manual staff }\end{array}$ & $\begin{array}{l}, 75 \\
, 89 \\
, 89 \\
, 76\end{array}$ \\
\hline $\begin{array}{l}\text { 6. Merit-Pay Bundle } \\
\text { Eigenvalue: } 2,74 \\
\% \text { of Variance Explained: } 4,49\end{array}$ & $\begin{array}{l}\text { Offer merit pay for management } \\
\text { Offer merit pay for professional staff } \\
\text { Offer merit pay for clerical staff } \\
\text { Offer merit pay for manual staff }\end{array}$ & $\begin{array}{l}, 72 \\
, 87 \\
, 89 \\
, 75\end{array}$ \\
\hline
\end{tabular}




\begin{tabular}{|c|c|c|}
\hline $\begin{array}{l}\text { Strategic Human Resource } \\
\text { Bundles (Factors) }\end{array}$ & $\begin{array}{l}\text { Human Resource Practices included in each } \\
\text { Bundle (Factor) }\end{array}$ & $\begin{array}{l}\text { Factor } \\
\text { Loadings }\end{array}$ \\
\hline $\begin{array}{l}\text { 7. Joint HR-Mgt Bundle } \\
\text { Eigenvalue: } 2,47 \\
\% \text { of Variance Explained: } 4,04\end{array}$ & $\begin{array}{l}\text { Responsibility is joint between HR and line } \\
\text { management for: } \\
\text { Compensation and benefits } \\
\text { Recruitment and selection } \\
\text { Training and development } \\
\text { Industrial relations } \\
\text { Staff reduction/expansion }\end{array}$ & $\begin{array}{l}, 69 \\
, 75 \\
, 72 \\
, 57 \\
, 67\end{array}$ \\
\hline $\begin{array}{l}\text { 8. Communication on Strategy } \\
\text { Bundle } \\
\text { Eigenvalue: } 2,44 \\
\% \text { of Variance Explained: } 3,99\end{array}$ & $\begin{array}{l}\text { Professional staff briefed about strategy } \\
\text { Clerical staff briefed about strategy } \\
\text { Manual staff briefed about strategy }\end{array}$ & $\begin{array}{l}, 74 \\
, 89 \\
, 86\end{array}$ \\
\hline $\begin{array}{l}\text { 9. Communication on Finance } \\
\text { Bundle } \\
\text { Eigenvalue: } 2,29 \\
\% \text { of Variance Explained: } 3,76\end{array}$ & $\begin{array}{l}\text { Professional staff briefed about finance } \\
\text { Clerical staff briefed about finance } \\
\text { Manual staff briefed about strategy finance }\end{array}$ & $\begin{array}{l}, 77 \\
, 85 \\
, 80\end{array}$ \\
\hline $\begin{array}{l}\text { 10. Communication on Change } \\
\text { Bundle } \\
\text { Eigenvalue: } 2,29 \\
\% \text { of Variance Explained: } 3,76\end{array}$ & $\begin{array}{l}\text { Communication through team briefings } \\
\text { Employee ideas communicated directly to sen- } \\
\text { ior management } \\
\text { Employee ideas communicated through the } \\
\text { immediate supervisor } \\
\text { Employee ideas communicated through work- } \\
\text { force meetings } \\
\text { Employee ideas communicated through the } \\
\text { use of team briefings }\end{array}$ & $\begin{array}{l}, 64 \\
, 65 \\
, 59 \\
, 66 \\
, 75\end{array}$ \\
\hline $\begin{array}{l}\text { 11. Communication on Organi- } \\
\text { zation of Work Bundle } \\
\begin{array}{l}\text { Eigenvalue: } \quad 2,25 \\
\% \text { of Variance Explained: } 54,04\end{array}\end{array}$ & $\begin{array}{l}\text { Professional staff briefed about organization of } \\
\text { work } \\
\text { Clerical staff briefed about organization of } \\
\text { work } \\
\text { Manual staff briefed about strategy organiza- } \\
\text { tion of work }\end{array}$ & $\begin{array}{l}, 72 \\
, 83 \\
, 85\end{array}$ \\
\hline $\begin{array}{l}\text { 12. Career Bundle } \\
\text { Eigenvalue: } 2,16 \\
\% \text { of Variance Explained: } 3,54\end{array}$ & $\begin{array}{l}\text { Regularly use of formal career plans } \\
\text { Regularly use of succession plans } \\
\text { Regularly use of planned job rotation } \\
\text { Regularly use of high flier schemes } \\
\text { Regularly use of international experience } \\
\text { schemes }\end{array}$ & $\begin{array}{l}, 56 \\
, 55 \\
, 55 \\
, 69 \\
, 62\end{array}$ \\
\hline $\begin{array}{l}\text { 13. Wider-Jobs Bundle } \\
\text { Eigenvalue: } 2,11 \\
\% \text { of Variance Explained: } 2,11\end{array}$ & $\begin{array}{l}\text { Jobs made wider for management } \\
\text { Jobs made wider for professional staff } \\
\text { Jobs made wider for clerical staff } \\
\text { Jobs made wider for manual staff }\end{array}$ & $\begin{array}{l}, 68 \\
, 76 \\
, 76 \\
, 65\end{array}$ \\
\hline $\begin{array}{l}\text { 14. Communication to Manage- } \\
\text { ment Bundle } \\
\text { Eigenvalue: } 1,92 \\
\% \text { of Variance Explained: } 3,14\end{array}$ & $\begin{array}{l}\text { Management briefed about strategy } \\
\text { Management briefed about finance } \\
\text { Management briefed about organization of } \\
\text { work }\end{array}$ & $\begin{array}{l}, 64 \\
, 73 \\
, 66\end{array}$ \\
\hline $\begin{array}{l}\text { 15. RIFs Bundle } \\
\text { Eigenvalue: } 1,47 \\
\% \text { of Variance Explained: } 2,40\end{array}$ & $\begin{array}{l}\text { Staff decreased by voluntary redundancy } \\
\text { Staff decreased by redeployment } \\
\text { Outsourcing used instead of staff reduction }\end{array}$ & $\begin{array}{l}, 73 \\
, 73 \\
, 59\end{array}$ \\
\hline
\end{tabular}


Next, logistic regression analysis was conducted between the resulting Strategic HR Bundles and Business Performance. From this analysis, the Strategic HR Bundles statistically significant with Business Performance were the following: Training Bundle, ShareOptions Bundle, Profit-Sharing Bundle, Communication on Finance Bundle, Communication on Organization of Work Bundle, Wider-Jobs Bundle, RIFs Bundle. As shown in Table 2, the first six bundles had a positive and the last had a negative relationship with performance.

Table 2: Logistic Model on the Relationship between Strategic HR Bundles and Business Performance for the EU

\begin{tabular}{|c|c|c|c|}
\hline Independent Variables: Strategic HR Bundles. & B & S.E. B & P-Value \\
\hline Training Bundle & 0.32 & 0.05 & $0.00 *$ \\
\hline Share-Options Bundle & 0.11 & 0.05 & $0.03 *$ \\
\hline Evaluation of HR Bundle & 0.03 & 0.04 & 0,46 \\
\hline Profit-Sharing Bundle & 0.20 & 0.05 & 0,00 * \\
\hline Group-Bonus Bundle & 0.05 & 0.05 & 0.25 \\
\hline Merit-Pay Bundle & 0.04 & 0.05 & 0.46 \\
\hline Joint HR-Management Bundle & 0.09 & 0.06 & 0.14 \\
\hline Communication on Strategy Bundle & -0.03 & 0.05 & 0.59 \\
\hline Communication on Finance Bundle & 0.13 & 0.05 & 0.01 * \\
\hline Communication on Change Bundle & 0.03 & 0.05 & 0.62 \\
\hline Communication on Organization of Work Bundle & 0.10 & 0.05 & 0.04 * \\
\hline Career Bundle & 0.05 & 0.05 & 0.35 \\
\hline Wider-Jobs Bundle & 0.13 & 0.05 & $0.01^{*}$ \\
\hline Communication to Management Bundle & 0.06 & 0.06 & 0.27 \\
\hline RIFs Bundle & -0.21 & 0.05 & 0.00 * \\
\hline Constant & -0.98 & 0.06 & 0.00 * \\
\hline
\end{tabular}

Dependent Variable: Business Performance.

Note: ${ }^{*} p<.05$, two tailed test. Cox \& Snell R Square of the model is $5.6 \%$. Overall Percentage of Correct Classifications is $70.4 \%$.

\section{Discussion}

From the above procedure, we find empirical support for the configurational approach with the emergence of fifteen Strategic HR Bundles indigenous to the EU. Furthermore, six of the bundles are positively and one is negatively connected to performance. These results provide a first step for management in the various EU businesses to see how human resources can be used strategically as a source of sustainable competitive advantage. Furthermore, the results serve as a blueprint for management to follow in evaluating closely organizational practices, adopting those positively and avoiding those negatively related to performance, to achieve its performance goals.

Specifically, the Training Bundle covers the monitoring and evaluation of training. In addition, a separate Career Bundle emerged in this study, which includes different career development schemes such as succession, high-flyer and international experiences. Certain training and development practices cited in the literature and included in the analysis, such as analyzing employee training needs, assessment centers and 
evaluation systems used in career development did not emerge as part of the bundles, suggesting that as far as the EU is concerned, these practices may not be important at present. Nevertheless, the overall significance of training and developing employees is consistent with existing research suggesting that training and development add value to an organization by maximizing productivity; enriching employee skills; and helping the organization to confront external pressures more effectively (Peteraf, 1993).

Furthermore, US-based research studies revealed a positive relationship between training and development activities and organizational performance (Youndt et al. 1996). In the present study, only the Training and not the Career Bundle was related to performance. Possibly the different schemes pertaining to career development may not be directly, but indirectly, connected to performance through other practices. Or, possibly these career development schemes, since they deal with future work, have an effect on future rather than immediate performance. If the latter is the case, then longitudinal studies on the subject would be more appropriate and enlightening.

No bundles emerged in relation to benefits while four bundles emerged in relation to compensation practices. The results with respect to benefits are not surprising since many of those cited as important for firms to offer in the predominantly USbased literature may be taken for granted in the European system. Europe overall enjoys a highly structured welfare system much more developed than in the US (Sparrow/Hiltrop, 1997; Brewster/Mayrhofer/Morley,. 2004). With respect to compensation though, Europe may not be so different from the US since according to existing research in both parts of the world, compensation must be fair and externally competitive to attract and retain the best employees and to motivate them to do a good job towards superior business performance (Koch/McGrath, 1996; Trevor/Gerhart/Boudreau, 1997; Pfeffer/Veiga, 1999; Cunha et al. 2002). In this respect, two out of the four emerging bundles in this study related to compensation, namely Share-Options and Profit-Sharing among all levels of employees including clerical and manual staff were significantly related to performance. The other two, Group-Bonus and Merit-Pay, again among all levels of employees, do not seem connected at present to performance. This differentiation among compensation bundles and their relation to performance may be indicative of the indigenous EU socio-cultural system, possible legal systems and normative business practices (Pendleton et al. 2003). Certainly further in-depth investigation as to the reasons for these results is warranted.

Another set of bundles emerging from this study has to do with the planning role of HR within the business context. These are the Evaluation of HR and the Joint HRManagement Bundles. While existing research cites planning HR activities strategically as a means to an effective co-ordination of all HR practices, thus helping towards sustainable competitive advantage and higher performance (Koch/McGrath, 1996; Wright/Dunford/Snell, 2001), none of the two planning related bundles was significantly connected to performance in the EU. A possible explanation here is responsiveness to planning, where its effects on performance are evident in the future and not at the time where it is performed (Brewster/ Mayrhofer/ Morley, 2004).

However, the majority of HR planning related practices identified in the literature (see Appendix 1) did not even form bundles. This raises questions as to the role that HR holds presently with respect to organizational strategy among EU businesses. Cer- 
tainly further investigation of the reasons that such practices were not part of bundles is warranted.

In contrast to the scarcity of planning practices in forming bundles, communication practices were abundant. Specifically, a set of five bundles related to communication practices involved briefing employees at different levels about business strategy, finances and organization of work as well as encouraging employees to communicate their ideas through more participative methods (i.e. workforce meetings, team briefings, directly to supervisors/managers). Furthermore, communication to management was separate in the results from communication to other employees, such as professional, clerical and manual staff, about the business, suggesting some form of traditionalism in hierarchies. Out of those, the bundles significantly related to performance involved Communication on Organization of Work and Communication on Finance among professional, clerical and manual staff but not among management. Communication of such data to management is all but universal and hence would not be a differentiator, but performance becomes significantly different once other categories of staff are kept informed as well. Pfeffer (1994) suggests that sharing information on various issues such as the organization's strategy or vision shows employees at various levels that they are trusted and given a significant job to do. In turn, employees will reciprocate this trust through their efforts to improve organizational performance.

Finally, in relation to staffing practices, two important bundles emerged, both of which were significantly related to performance. Wider-Jobs Bundle is related to widening job descriptions at all organizational levels, which is positively related to performance. This result is consistent with current research on the importance of work flexibility and multitasking through job definition and design as well as the market system of the configurational approach (Delaney et al. 1989; Huselid, 1995; Delery/Doty, 1996). RIFs Bundle is related to the way EU businesses handle reduced staffing needs through voluntary turnover, redeployment and outsourcing. Even through these methods are less hard on employees than mandatory retirement or layoffs, their relation to performance in this study is inverse. A brief review of literature on downsizing practices provides reinforcement for the present results (Lee/Miller, 1999; de Meuse et al. 2004; Chadwick/Hunter/Walston, 2004).

In summary, the study results suggest that successful EU businesses seem to be converging towards utilizing SHRM as a competitive tool. The results of this study are encouraging in revealing fifteen common bundles, of which seven are significantly related to performance, among such a large and diverse set of countries. Even though not completely there yet, HRM in the EU is viewed strategically as a competitive tool to a certain extent, involving certain human resource management practices, and in turn bundles, more than others. In this respect, the link of Strategic HR Bundles to business performance in the EU is not a myth (Brewster, 1995; Harris/Ogbonna, 2001), but rather a work in progress.

\section{Conclusions}

This study addresses an important issue for the competitiveness of organizations, especially in the EU, given the requisite utilization of their human resources. Achieving sustainable competitive advantage through people, even though not fully utilized at 
present, may result from a combination of human resource management practices used strategically. In turn, HR managers in collaboration with colleagues must understand these combinations and develop the appropriate strategies in order to help their organizations capitalize on their strengths and address their weaknesses if they want to achieve sustainable competitive advantage through people. In doing so, they must be careful not to ignore organizational and national idiosyncrasies as well as differing social and legislative frameworks. Nevertheless, as shown in the present study, they may work within the EU collective context, in which common directions and strategies for HRM may be enforced.

Despite its contribution, this study may be improved and expanded in several ways in addition to those already suggested in the previous section. For instance, the EU does not have to be the only basis for exploration. Similar studies may be conducted for other parts of the world such as the US or Asia, since comparable data exist through the CRANET questionnaire. Such an exploration would provide for a more robust investigation of the subject and would show differences and similarities among different countries or between the EU and other parts of the world.

For the future, improved versions of the CRANET survey may incorporate input from multiple sources or even performance variables that are more quantitative in nature. Furthermore, researchers may complement the questionnaire with interviews or other methods of data collection in order to conduct a more in depth investigation of the relationship between HR and performance.

Finally, the present study may be enhanced to align the way human resources are managed with organizational strategic needs. Focusing on the interactions between organizational strategy and human resource management within a social context may enable management in organizations to choose the forms and styles of managing human resources that are the most appropriate for them. In turn the appropriate levels of partnership between employees and employers as well as managerial and nonmanagerial staff will be determined and possibly enhanced.

\section{References}

Barney, J. B. (1991): Firm Resources and sustained competitive advantage. In: Journal of Management, 17: $99-120$.

Barney, J. B. (2001): Is the resource-based 'view' a useful perspective for strategic management research? Yes. In: Academy of Management Review, 26: 41.

Becker B./Gerhart B. (1996): The impact of human resource management on organizational performance: Progress and prospects. In: Academy of Management Journal, 39: 779-802.

Bernadin H. J./Russell J. (1993): Human resource management: An experiential approach. London: McGraw-Hill.

Blum, E./Clegg, R. (2003): Percent plans: Admissions of failure. In: The Chronicle of Higher Education, 49: B10-B11.

Boxall, P. (1994): The strategic HRM debate and the resource-based view of the firm. In: Human Resource Management Journal, 6: 59-75.

Boxall, P./Steeneveld, M. (1999): Human resource strategy and competitive advantage: A longitudinal study of engineering consultancies. In: Journal of Management Studies, 36: 443-463.

Brewster, C. (1995): Towards a European model of human resource management. In: Journal of International Business Studies, 26: 1-21.

Brewster, C./Harris, H. (1999): International human resource management: Contemporary Issues in Europe. London: Routledge. 
Brewster, C./Mayrhofer, W./Morley, M. (2004): Human resource management in Europe: Evidence of convergence. London: Elsevier.

Chadwick, C./Hunter, L. W./Walston, S. L. (2004): Effects of downsizing practices on the performance of hospitals. In: Strategic Management Journal, 25: 405-427.

Cunha, R./Cunha, M. P./Morgado, A./Brewster, C. (2002): Market impacts on strategy, HRM practices and organizational performance: Toward a European model. In: Management Research, 1: 79-91.

De Meuse, K. P./Bergmann, T. J./Vanderheiden, P. A./Roraff, C. E. (2004): New evidence regarding organizational downsizing and a firm's financial performance: A long-term analysis. In: Journal of Managerial Issues, 16: 155-79.

Delery, J. E. (1998): Issues of fit in strategic human resource management: Implications for research. In: Human Resource Management Review, 8: 289-309.

Delery, J. E./Doty, D. H. (1996): Modes of theorizing in strategic human resource management: Tests of universalistic, contingency, and configurational performance predictions. In: Academy of Management Journal, 39: 802-835.

Delaney, J. T./Huselid, M. A. (1996): The impact of human resource management practices on perceptions of organizational performance. In: Academy of Management Journal, 39: 949-970.

Delaney, J./Lewin, D./Ichniowski, C. (1989): Human Resource Policies and Practices in American Firms. Washington, DC: U.S. Government Printing Office.

Down, J. W./Mardis, W./Connolly, T. R./Johnson, S. (1997): A strategic model. In: HR Focus, 74: 2224.

Dube, L./Renaghan, L. H. (1999): Sustaining competitive advantage. In: Cornell Hotel \& Restaurant Administration Quarterly, 40: 27.

Elsdon, R./Iyer, S. (1999): Creating value and enhancing retention through employee development: The Sun Microsystems experience. In: Human Resource Planning, 22: 39-48.

Ferris, G. R./Hochwarter, W. A./Buckley, M. N./Harrell-Cook, G./Frink, D. D (1999): Human resources management: Some new direction. In: Journal of Management, 25: 385-418.

Flanagan, D. J./Deshpande, S. P. (1996): Top Management's perceptions of changes in HRM practices after union elections in small firms: Implications for building competitive advantage. In: Journal of Small Business Management, 34: 23-35.

Fox, D./Byrne, V./Rouault, F. (1999): Performance improvement: What to keep in mind. In: Training \& Development, 53: 38.

Gannon, M. J./Flood, P. C./Paauwe, J. (1999): Managing human resources in the third era: Economic perspectives. In: Business Horizons, 42: 41-48.

Harris, L. C./Ogbonna, E. (2001): Strategic Human resource management, market orientation, and organizational performance. In: Journal of Business Research, 51: 157-166.

Hax, A. C./Wilde, D. L. II. (1999): The Delta model: Adaptive management for a changing world. In: Sloan Management Review, 40: 11.

Huselid, M. A. (1995): The impact of human resource management practices on turnover, productivity, and corporate financial performance. In: Academy of Management Journal, 38: 635-672.

Huselid, M. A./Jackson, S. E./Schuler, R. S. (1997): Technical and strategic human resource management effectiveness as determinants of firm performance. In: Academy of Management Journal, 40: 171189.

Ichniowski, C./Shaw, K./Prennushi, G. (1997): The effects of human resource management practices on productivity: A study of steel finishing lines. In: American Economic Review, 87: 291-312.

Jackson, S. E./Schuler, R. S. (2000): Managing Human Resources: A Partnership Perspective. New York, NY: South-Western College Publishing.

Jap, S. D. (2001): "Pie sharing" in complex collaboration contexts. In: Journal of Marketing Research, 38: 86-100.

Kerr, D./Beaujot, R. (2002): Family relations, low income and child outcomes: A comparison of Canadian children in intact-, step-, and lone-parent families. In: International Journal of Comparative Sociology, 43: 134-153.

Koch, M. J./McGrath, R. G. (1999): Improving labor productivity: Human resource management policies do mater. In: Strategic Management Journal, 17: 335-354. 
Lado, A. A./Boyd, N. G./Wright, P. (1992): A competency-based model of sustainable competitive advantage: Toward a conceptual integration. In: Journal of Management, 18: 77-92.

Lado, A. A./Wilson, M. C. (1994): Human resource systems and sustained competitive advantage: A competency based perspective. In: Academy of Management Review, 19: 699-728.

Lahteenmaki, S./Vanhala, S. (1998): HRM and company performance: the use of measurement and the influence of economic cycles. In: Human Resource Management Review, 8: 51-65

Lee, J./Miller, D. (1999): People matter: Commitment to employees, strategy and performance in Korean firms. In: Strategic Management Journal, 20: 579-593.

MacDuffie, J. P. (1995): Human resource bundles and manufacturing performance: Organizational logic and flexible production systems in the world auto industry. In: Industrial and Labor Relations Review, 48: 197-221.

Marchington, M./Grugulis, I. (2000): "Best Practice" human resource management: perfect opportunity or dangerous illusion? In: International Journal of Human Resource Management, 11: 1104-1124.

Pearce, J./Robbins, D. K./Robinson, R. B. (1987): The impact of grand strategy and planning formality on financial performance. In: Strategic Management Journal, 8: 125-135

Pendleton, A./Poutsma, E/Van Ommeren, J./Brewster, C. (2003): The incidence and determinants of employee share ownership and profit sharing in Europe. In Kato, T./Pliskin, J. (eds.): The Determinants of the incidence and effects of participatory organizations. Advances in the Economic Analysis of Participatory and Labor Management, Volume 7, Greenwich: JAI Press.

Perry-Smith, J. E./Blum, T. C. (2000): Work-family human resource bundles and perceived organizational performance. In: Academy of Management Journal, 43: 1107-1117.

Petaraf, M. A. (1993): The cornerstones of competitive advantage: A resource-based view. In: Strategic Management Journal, 14: 179-192.

Pfeffer, J. (1994): Competitive advantage through people: Unleashing the power of the workforce. Boston: Harvard Business School Press.

Pfeffer, J./Veiga, J. F. (1999): Putting people first for organizational success. In: The Academy of Management Executive, 13: 37.

Pickles, L. J./Bookbinder, S. M./Watts, C. H. (1999): Building the HR value chain. In: Employment Relations Today, 25: 21-23.

Rank, R. M./Hirschl, A. T. (2001): Rags or riches? Estimating the probabilities of property and affluence across the adult American life span. In: Social Science Quarterly, 82: 651-670.

Sherman, H. D./Young, S. D./Collingwood, H. (2003): Profits you can trust: spotting \& surviving accounting landmines. Saddle River: Pearson Education, Inc.

Shrader, R. C. (2001): Collaboration and performance in foreign markets: The case of young hightechnology manufacturing firms. In: Academy of Management Journal 44: 45-58.

Smith, J. B./Barclay, D. W. (1997): The effects of organizational differences and trust on the effectiveness of selling partner relationships. In: Journal of Marketing, 61: 3-21.

Snell, S. A./Youndt, M. A./Wright, P. M. (1996): Establishing a framework for research in strategic human resource management: Merging resource theory and organization learning. In: Research in Personnel and Human Resources Management, 14: 61-90.

Sparrow, P. R./Hiltrop, J. M. (1997): Redefining the field of European human resource management: A battle between national mindsets and forces of business transition? In: Human Resource Management, 36: 201-219.

Swiercz, P. M./Spencer, B. A. (1992): HRM and sustainable competitive advantage: Lessons from Delta Air Lines. In: Human Resource Planning, 5: 35-47.

Taylor, S./Beechler, S./Napier, N. (1996): Toward an integrative model of strategic international human resource management. In: Academy of Management Review, 21: 959-986.

Tabachnick, B. G./Fidell, L. S. (2000): Using Multivariate Statistics. (4th ed.) New York: Allyn and Bacon Inc.

Trevor, C. O./Gerhart, B./Bourdeau, J. W. (1997): Voluntary turnover and job performance: Curvilinearity and the moderating influences of salary growth on promotion. In: Journal of Applied Psychology, 82: 44-62. 
Ulrich, D./Lake, D. (1990): Organizational Capability: Competing from the Inside out. New York, NY: Wiley.

Welbourne, T. M./Andrews, A. O. (1995): Predicting performance of initial public offerings: Should human resource management be in the equation? In: Academy of Management Journal, 39: 891-919.

Wiggins, R. R./Ruefli, T. W. (2002): Sustained competitive advantage: Temporal dynamics and the incidence and persistence of superior economic performance. In: Organization Science, 13: 82-108.

Wright, P. M./Dunford, B. B./Snell, S. A. (2001): Human resources and the resource based view of the firm. In: Journal of Management, 27: 701-722.

Wright, P. M./Mc Mahan, G. C. (1992): Theoretical perspectives for strategic human resource management. In: Journal of Management, 18: 292-320.

Wright, P. M./Mc Mahan, G. C./McGormick, B./Sherman, S. (1998): Strategy, core competence and HR development as determinants of HR effectiveness and refinery performance. In: Human Resource Management, 37: 17-29.

Youndt, M. A./Scott, S. A./Dean, J. W./Lepak, D. P. (1996): Human resource management, manufacturing strategy and firm performance. In: Academy of Management Journal, 39: 836-867.

\section{Appendix 1: Original Items used in the Principal Components Analysis}

\begin{tabular}{|c|c|}
\hline HRM Functions & Strategic Human Resource Management Practices \\
\hline Planning & $\begin{array}{l}\text { Organizations with HR Dept; Head of HR on governing board; Organizations with } \\
\text { HR strategy; HR involvement in corporate strategy; Performance of HR Dept. } \\
\text { Evaluated; Evaluations taking into account the views of: top management, line } \\
\text { management, employees, human resource managers; HR Dept. with line manag- } \\
\text { ers have the primary responsibility for: compensation and benefits, recruitment } \\
\text { and selection, training and development, industrial relations, staff reduc- } \\
\text { tion/expansion }\end{array}$ \\
\hline Staffing & $\begin{array}{l}\text { Staff decreased by voluntary redundancy; Staff decreased by redeployment; Out- } \\
\text { sourcing used instead of staff reduction; Vacancies filled internally for: senior, } \\
\text { middle, junior management; Jobs made wider for: management, professional } \\
\text { staff, clerical staff, manual staff }\end{array}$ \\
\hline $\begin{array}{l}\text { Training \& } \\
\text { Development }\end{array}$ & $\begin{array}{l}\text { Analyze employee training needs; Monitor effectiveness of training; Evaluate } \\
\text { training: learning, behaviors, results, reaction; Regularly use: formal career plans, } \\
\text { assessment centers, succession plans, planned job rotation, high flier schemes, } \\
\text { international experience schemes; Evaluation system used in career development }\end{array}$ \\
\hline $\begin{array}{l}\text { Compensation } \\
\text { \& Benefits }\end{array}$ & $\begin{array}{l}\text { Offer employee share options for: management, professional staff, clerical staff, } \\
\text { manual staff; Offer profit sharing options for: management, professional staff, } \\
\text { clerical staff, manual staff; Offer group bonus for: management, professional staff, } \\
\text { clerical staff, manual staff; Offer merit pay for: management, professional staff, } \\
\text { clerical staff, manual staff; Offer workplace childcare; Offer childcare allowances; } \\
\text { Offer career break scheme; Offer maternity leave; Offer paternity leave; Offer } \\
\text { pension scheme; Offer education/training break }\end{array}$ \\
\hline $\begin{array}{l}\text { Communication } \\
\text { \& Participation }\end{array}$ & $\begin{array}{l}\text { Communication verbally direct to employees; Communication written to employ- } \\
\text { ees; Communication in use of computer mail; Communication through team brief- } \\
\text { ings; Management briefed about: strategy, finance, organization of work; Profes- } \\
\text { sional staff briefed about: strategy, finance, organization of work; Clerical staff } \\
\text { briefed about: strategy, finance, organization of work; Manual staff briefed about: } \\
\text { strategy, finance, organization of work; Employee ideas communicated: directly to } \\
\text { senior management, through the immediate supervisor, through workforce meet- } \\
\text { ings, through the use of team briefings }\end{array}$ \\
\hline
\end{tabular}

